\title{
A Study of the Influence of the Physical Changes in the Built Environment on the Changing Character of the Place: an SIRN Approach
}

\author{
Nileesha Senavirathna and Jagath Munasinghe \\ Department of Town \& Country Planning, University of Moratuwa, Sri Lanka \\ dulanjaleesenevirathna@gmail.com and jagathnm@gmail.com
}

\begin{abstract}
The relationship between the 'constituents of a place' and its 'character' has throughout been a matter of research for many studies in planning and urban design. In all previous studies this relationship has often been conceptualized as one-way process based upon environmental determinism. Therefore, character of a place is conventionally regarded as a static phenomenon affected by the physical changes in the built environment. Contesting this conventional understanding, this study models the relationship between the physical environment of a place and its character as a mutually trading and ever evolving phenomenon that has to be conceptualized only through a comprehensive understanding of the process than the resultant static end-situations. With the changing urban environment in a major street in Colombo this study demonstrates that individuals' experience shapes the place character and the same character generated by the individuals' reproduction process of the place in turn shapes their own experience, and such experience then shapes their cognition of the place, which is a cuclic process. The demonstrative model suggests that neither the memory of the place nor the perception of its character are internal to individuals, while neither the shaping of the physical environment nor the generated character of the place are external to its users. Rather, the place, its charterer and its experience are results of a process of transactions between the place and its users. Such a comprehensive understanding of the complexity of a place character is important for planners and urban designers to successfully engage in making responsive urban environments. The study is based on the concept of 'Synergetic Inter-Representation Network Model' proposed by Portugali and Haken (1996) and the 'Transactional theory' by Wapner (1987) to model the character of the place and its relationship with the physical environment in a novel manner. The physical changes in the environment and the user experience are elicited in the form of participatory observation, sketch maps, photographic surveys and in-depth interviews.
\end{abstract}

\section{Introduction}

Analyses of the place character are often vague and implicit. Because, the place is an evolutionary concept in the life of a human being; it reveals the external bonds of a person's existence, and it is a profound and complex aspect of his or her experience of the world (Dayarathna, 1998). Proceeding on the transactional perspective, the environment or a place what we experience is an evolving phenomenon thus our memory is accumulated internally to us similarly externally to the environment. Therefore, the place character is not something out there in the environment as most of the studies conventionally suggest that place character is often limit to physical understanding, and not something we construct in our mind as constructionists suggest of a composition of the psychological paradigms. But, Place character is a process of experiencing of the environment as a result of 'what is there', as well 'we reconstruct' a result of our own behavior on our previous knowledge of the place with what was contributed by the others. However, less attention is paid to understand a place is an evolving phenomenon; therefore its character is also evolving with time. What makes that evolution and how it happens is not studied much hitherto.

On that basis, the argument is developed as the environment what we experience is not the 
planned or built by the government, but it is resulting from the user's responses to what was built by the government. It is important to have this understanding, because planners and urban designers generally conceptualize a place and its character as a static state and therefore plan and design for that. Hence, this research study is going to examine the aforesaid argument regarding changes in the physical environment on changing perceived place character on the selected nodes of the Galle road, Colombo to model the relationship between the physical environment of a place and its character as a mutually trading and ever evolving phenomenon that has to be conceptualized only through a comprehensive understanding of the process than the resultant static end-situations as a novel manner.

\section{Studies on the 'Place' and the 'Place Character'}

Place character or an entity would be a special feature which differs from the rest of the environment which particular place or entity fits. Several scholars have described the place character in different conceptual approaches, but there is not seem to have a commonly shared theoretical orientation of the world accepted definition among the context of design and the planning professionals to recognize and reinforce the intrinsic place character, whereby human experiences and human actions are sensitized and meaningfully intervened.

However, image, sense of place, character and genius loci are not totally different terms, but distinctly which operate at different stages; in many cases they have served as effective synonyms for 'character of the place' itself often misused. (Jivén, Gunila, Larkham, \& Peter, 2003).The place character is enriched by the composition of its physical, social, and psychological paradigms. Therefore, most of the theoretical background were explored the character under the above distinct directions. Both Phenomenologists and psychologists have attempted to define the place Character (Schultz, 1980; Canter, 1977) as an approach to studying the people and the place is known as "Phenomenology"; according Husserl (1962), it has been defined as the 'science of being' is. They are described place holds within our nature and predominantly as a physical component highly based on aesthetic evaluations. "..Diverse action, demand places with a different character. A dwelling has to be 'protective', an office 'practical', a ballroom 'festive' and a church 'solemn'...” (Schulz, 1976).

Relph (1976) weights more towards place character on a phenomenological approach based on human experiences; "my place is the province or region, which that I live, or the city or the street or the house that is my home'. In other words, place would be a socio-physical unit of the environment which experience, forming and co-behavioral pattern in the environment.

Canter (1977) is explored the place character as a psychologically endowed entity. It follows that we have not fully identified the 'place' until we know what behavior is connected with, or it is expected will be housed in, 1. Given locus, 2. What is the physical parameter of the setting? And 3 . Description of which place holds on that behavior in that physical environment?

Alexander (1979) defined the place character more towards to the physical environment of what is visually on the ground, which reflects more of the character of a particular place. Understanding of each place is given its character by certain patterns of events that keep on occurring there'. These patterns of events are continually linked with certain geometric patterns in the space'. Each building creates its character from just the patterns which keep on repeating there. Since the place character is defined by patterns. Such a pattern may have much to do with the city's character (Southworth, 1991).

Similarly, Rapoport (1977; 1982; 1992; 1993) discussed non-visual attributes and activities also largely contribute to shape the place character. As very first experience is expressed the place character seen in street in India and bazaars in the Middle-East is generally expresses through the smell of food and incense in both non-visual characteristics. These sensory characteristics resulted from when different ethnic groups occupying the streets, engaging in activities such as culinary, 
smoking, and playing music. It has revealed that non-visual experiences also significant as can even more acute than visual experiences in identifying the character of an urban environment.

The 'making places tradition' underpinned by the idea that space become places due to the support provided by the built environment for the activities taking place there. Hence that, Rapoport (1990) theorized to an understanding of the activities which reflects the place character of the system of activities into a pattern of events is helpful to understand the place character. For an instance; street vending is an 'event' happening on the street. This 'specific event' of street vending happens in a specific place in a specific pattern in the street. Rapoport (1977, 1990) study on the Environment and behavior studies identifies the character of place predominately through activities as below:

1. What activity itself?

2. How it carried out?

3. How this activity is associated with other activities and combined into activity systems?

In summation, many preceding studies have revealed place character is often limited to visual attributes of the built environment as such 'qualitative and quantitative aspects of place contribute to its character. Limited scholarly attempts extended the place character to socioeconomic and psychological approaches describing on the people's behavior upon the daily life styles. According to the Fernando, (1999) and Nasar, (1997) emphasized that visual elements such as paths, edges, districts, nodes, and landmarks and Multi-Sensory elements of forms, shapes, sounds, colors, odors, Textures, kinesthetic/movement patterns, air temperature /light and shade are directly associated with the place character.

The Different Approaches on the Interaction of Inhabitant cognition and the Environment

\section{Environmental Determinism}

Munasinghe (2003) in his unpublished dissertation has discussed three major paradigms in the interaction of inhabitant on the place focus on environment and behavior studies. The classical theories of human and the environment relation were based on the perception of the built-environment had a role upon human. The environment was mostly taken in its physical sense and this physical setting was considered to be imposing conditions upon the peoples' behavior (Dayarathne, 2002). Most of the urban designers are followed this view and planed and designed the space. Therefore people have to accept it helplessly.

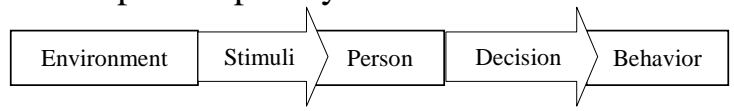

Figure 1 : Environmental Determinism (Munasinghe, 2003)

\section{Interractionist's World View}

Munasinghe, (2003) pointed out the relationship between the people and the environment was not as direct and casual, within the newly emerged interactional paradigm, but behavior was considered as a function of some attributes of people and some attributes of the environment and their interaction in a particular way (Werner and Altman, 2000; Dayaratne, 2002).

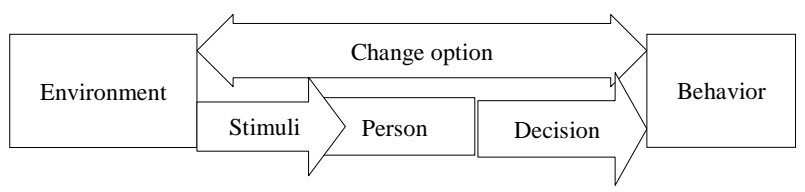

Figure 2 : The Interractionist's world view (Munasinghe, 2003)

\section{Transactional and Organism World View}

Munasinghe (2003) has described, the people and the environments are not static separate entities, but one having an impact on the other as seen in the interactions views. Rather, they are interlocked parts that continuously evolve through dialectic between them (Dayaratne, 2002). Neither the environment nor the individual persons are independent from every other, but they can be commonly demarcated within another (Altman, 1998). As simply explained, the environment what we experience is not only the physical; any experienced in the physical environment is also a part of the social context of internal 
stimulus in the brain (Stokhols, 1987) of inhabited people.

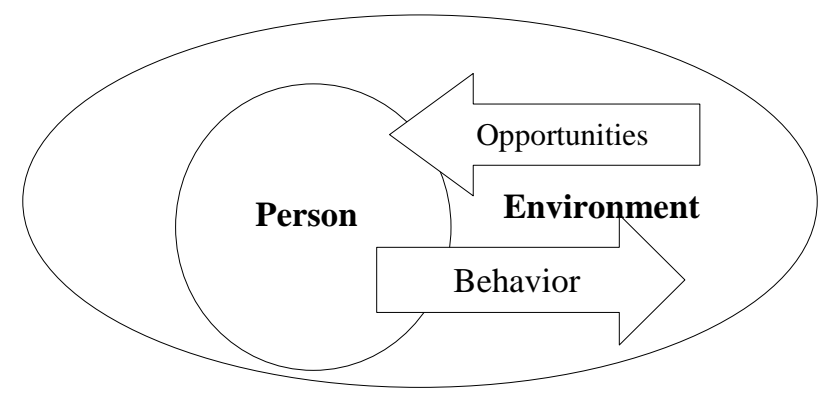

Figure 3 : Transactional and Organism World View (Munasinghe, 2003)

\section{Seymour Wapner's (1987) Transactional Theory}

Wapner has suggested any built environment is an evolution and not a static end state. At the early stages, we thought what we experience of our built environment is that what is designed by planners or urban designers. This paradigm is known as Environmental Determinism. But later it was shown that, what we experience is not only the physical environment which was changed by the planning authorities, but the people's responses to what they got; it is known as Interractionist's world view. Very recently, Transactional and Organism world view is revealed what we experience is not the first and not the second paradigms either, but the process of transaction between the user and the environment. In summation, this is can be described as an evolving process of transaction between the people and the environment under three stages such as offering, acceptance/behavior, and negotiation/modification and so on.

\section{Synergetic Inter-Representation Network (SIRN)}

The abbreviation SRIN is composed of two basics: Synergetic and Inter-Representation Network IRN). The notion of IRN was suggested by Juval Portugali (1996) as a challenge to both Behaviorisms; they considered the brain as a 'Black-box' (B-B) and human memory/cognition as an essentially external, stimulus-response process. Portugali,
(2002) describes human memory/ the cognitive system in general, and the one associated with cognitive system in particular, extend beyond the individual's mind/brain into the external environment.
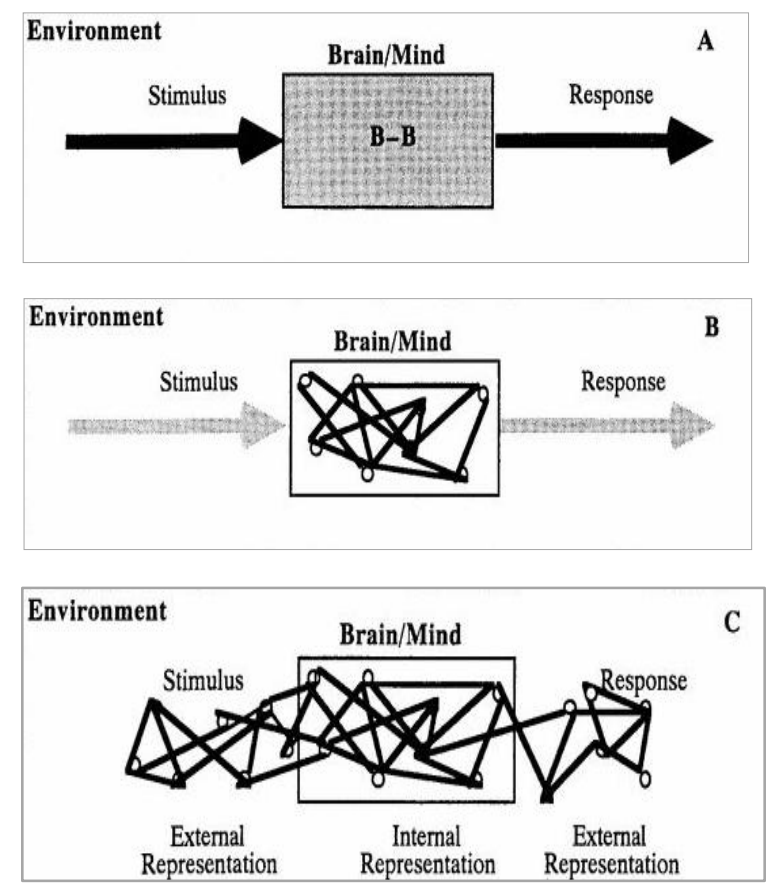

Figure 4: Early Studies on Cognition Portugali (1996)

(A) Behaviorism

(B) Classical View

(C) The IRN Approach

Early studies on cognition/memory as they were (Golledge, 1993) characteristically based on 'Behaviorism': approaches which mainly concern were the relations between Stimuli and Responses as they can be observed in the external environment. The mind/brain itself considered as a Black-box, the internal process of which cannot be directly observed, and therefore cannot be subject of a genuine scientific inquiry (Figure 4). 
Then, more recently following classical cognitive science, studies on cognition turned their attention to this $\mathrm{B}-\mathrm{B}$, in search of the internal processes of the mind, that is to say, to the way the mind/brain encodes stories and decodes information from the Comparing behaviorism and classical view, one can see that beyond the differences and the two approaches share a common property: in both mind and environment are perceived as two essentially independent, and casually related entities. In behaviorism, the relevant system of interest lies outside the B-B, in the environment; in classical cognitive scienceinside the B-B. The IRN Approach is so in the sense that the cognitive system is a network composed of internal and external representations, external representations are therefore, the product of the ability of humans to externally represent ideas, emotions, and thoughts and so on.
Synergetic is a theory developed by Haken (1996) to deal with open, complex and as such self-organizing systems. The notion of SIRN was developed and applied to several theoretical and empirical domains, including decision-making, planning discourse, information theory and exploratory behavior. Theory was extended and applied to several research fields including cognition and brain functioning.

Synergetic adds to the notion of IRN the view that the mind, cognition, cognitive mapping, and the interaction between internal and external representations, are all self-organizing systems that evolve in line with the principles of synergetic. SIRN is thus a model (see figure 05 ) and a theory that casts IRN into the formalism of synergetic.

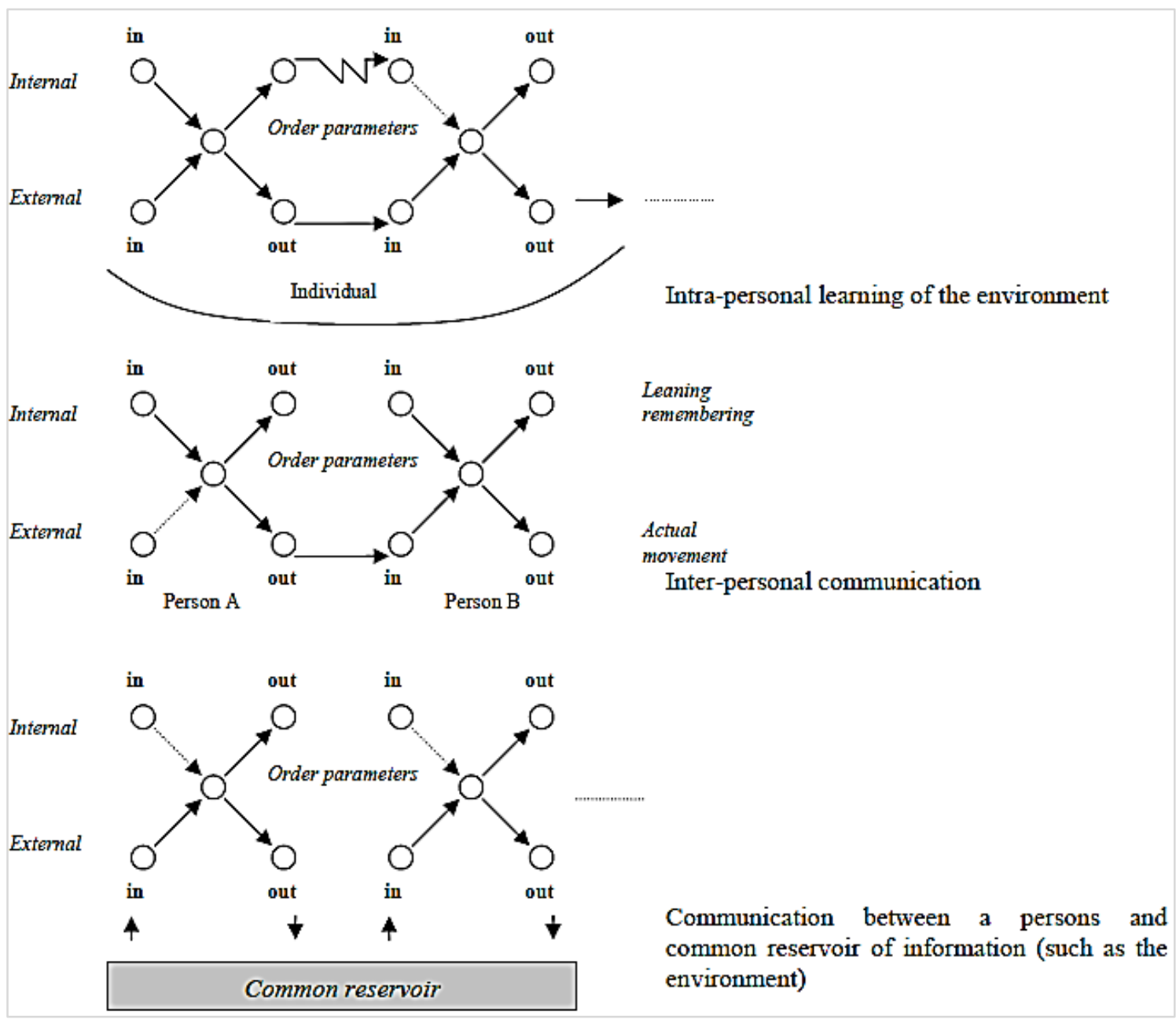

Figure 5: SIRN Model

Portugali (1996) 


\section{The Study}

This study intended to find the more comprehensive model to explain the 'evolving character of the place' in relation to its physical environment based on the Wapner's (1987) transactional theory and Portugali and Haken (1996) SIRN. Accordingly, identified two variables of the physical changes in the environment and the corresponding changes in the perceived place character, data collection was carried out; through the user's experience of the place considering two context of prior to the redevelopment and the after the redevelopment with the changing urban environment in a major street in Colombo this study select the three distinct nodes on the Galle road considering several criteria as follows (See table: 01).

\begin{tabular}{|l|l|}
\hline Criteria & Purpose \\
\hline $\begin{array}{l}\text { Periodical external } \\
\text { interventions } \\
\text { (Phenomenon) }\end{array}$ & $\begin{array}{l}\text { Subject to change the } \\
\text { physical setting }\end{array}$ \\
\hline $\begin{array}{l}\text { An urbanized street } \\
\text { with mix land use }\end{array}$ & $\begin{array}{l}\text { Consists multiply } \\
\text { users }\end{array}$ \\
\hline $\begin{array}{l}\text { A user with distinct } \\
\text { culture practices }\end{array}$ & $\begin{array}{l}\text { Culture is } \\
\text { determining activity } \\
\text { patterns of users }\end{array}$ \\
\hline $\begin{array}{l}\text { An availability of data } \\
\text { collection and A A } \\
\text { reliability to conduct } \\
\text { the methods of data } \\
\text { collection }\end{array}$ & $\begin{array}{l}\text { Minimize the gaps } \\
\text { and increase the } \\
\text { validity of required }\end{array}$ \\
\hline
\end{tabular}

Table 1: Criteria for selecting the Study Location Compiled by Author

Subsequently, formulated working definite for the place character as such "understanding of individual or group of people in relation to the environment', data collection is scoped and gathered data is a form of sentimental matters as such different stories, thoughts, etc. through the key informant in-depth interviews. The process of data collection is under the three distinct ways.

1. In-depth interviews are carried on 15 respondents including five from each location who representing various social groups, gender balance, professional and non-professionals, age groups, different employments, education levels and etc.
2. Sketch maps and Photographic survey are used in two different contexts as above mentioned at the same place to describe the changes of the physical settings and the behavior of the user.

3. Participatory observation and In-depth interviews are explicated the user behavior and to identify the changes by user's perception of the same place with two different contexts.

Table 2 : The Process of Data Collection Compiled by Author

The respondents' responses are consisted diverse ideas in the different perspective. In order to analysis, the content analysis technique is selected as the most appropriate way.

The views of each location were listed and ranked based on the repetition count. And responses were analyzed as a continuous set of information following the SIRN model. Gathered data are analyzed applying the content analysis technique. These interviews were conducted to investigate the way people experience the place character as discovered under the working definition. The followings are the focused areas of content of the indepth interviews.

\begin{tabular}{|c|l|}
\hline 1 & $\begin{array}{l}\text { How do you feel about the present } \\
\text { situation? }\end{array}$ \\
\hline 2 & $\begin{array}{l}\text { What can you remember about the past } \\
\text { situation of the same place? }\end{array}$ \\
\hline 3 & $\begin{array}{l}\text { Do feel a difference between then and } \\
\text { now, and if so What specific } \\
\text { Characteristics have changed? }\end{array}$ \\
\hline 4 & $\begin{array}{l}\text { How do you value the change, what are } \\
\text { positives, what are } \\
\text { Negatives? }\end{array}$ \\
\hline 5 & $\begin{array}{l}\text { How did you behave in it then and how } \\
\text { do you it now? }\end{array}$ \\
\hline 6 & $\begin{array}{l}\text { How do you think that the others } \\
\text { behaved in it and use it now? }\end{array}$ \\
\hline 7 & $\begin{array}{l}\text { Should the places change anymore and } \\
\text { if so what do you wish? }\end{array}$ \\
\hline
\end{tabular}

Table 3 : Content of the Focused Interviews Compiled by Author 


\section{Background of the Study Location}

The first intervention of redevelopment project of the Galle road was funded by World Bank in 1990. Later, several times, redevelopment is responded by local Authorities. This study is basically discussing the changes dividing the context prior to the redevelopment of the Metro Colombo Urban Development project (MCUDP) and after it.

In 2011 MCUDP is initiated and the implementation phase is planned to do in five years, commencing from 2012. The government of Sri Lanka has launched a program to transform Colombo and its metropolitan area into a metropolis of international standards which includes a number of sub-projects inclusive of improving public convenience facilities, walkability improvements and drainage improvements to build a better living environment for the people.

\section{The Results and Discussions}

The results have been organized in three phases as context prior to the redevelopment of the Galle road, Present context, and the users' expectations of further changes in the environment.

\section{User's Views on the Changes of the Environment}

The views of the people's at the present environment is identified based on ranking over the weighted attributes which describes majority of the interviewees had a positive repetition of the new environment after the redevelopment as calm and comfortable, cleanliness, Safe, relax, pleasant, healthy and shady (see table: 04).

Those identified responses are first level of attributes as often described by the users. All the interviewees have described their experience differently and they had to change their cognition of the place which had previously at the same place. This implies that they had a preconceived idea of the location, which comes out of their experience of the place at previous occasions.
Prior to the redevelopment

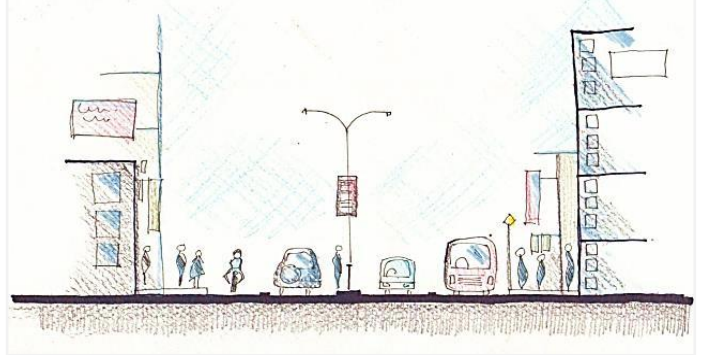

After the redevelopment

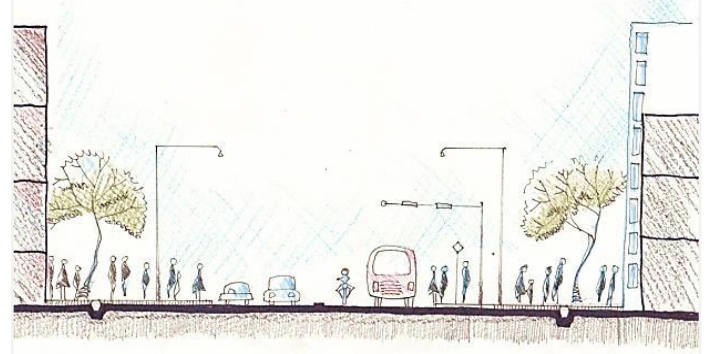

Figure 6 : Cross section of the Galle road at Kollupitiya junction and the vicinity (KJV)

Compiled by Author

Through the observation and the interviews, author has identified KJV itself consists with several changes similar to BJV. The main changes are identified as wider pavement with paved blocks, newly adapted street elements such as new bus stops, new traffic signal system, tree line, newly introduced adverting boards, etc. comparing prior to the environment changed (See figure:06).

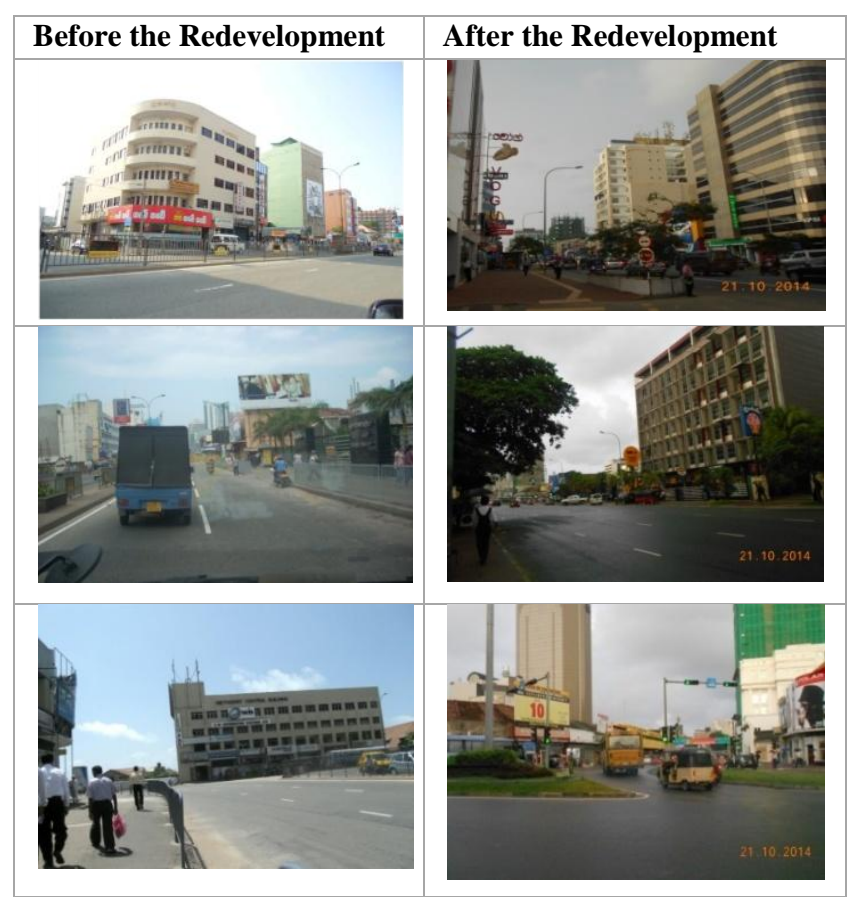

Figure 7: Views of KJV before and after the redevelopment 


\begin{tabular}{|c|c|c|}
\hline \multicolumn{3}{|c|}{$\begin{array}{l}\text { User views on the Present Environment } \\
\text { (First level of attributes in Three Different Locations) }\end{array}$} \\
\hline KOLLUPITIYA & BAMBALAPITIYA & WELLAWATTA \\
\hline New Environment & Clean & Environment is very good \\
\hline Comfortable & Comfort & Feel happy \\
\hline Calm & Calm environment & Comfortable environment \\
\hline $\begin{array}{l}\text { Impressed with beautiful } \\
\text { environment }\end{array}$ & Quite good rather past & Safe walking paths \\
\hline Newly added street elements & Less Congestion of people & Quite good rather past \\
\hline Shady & Shady & Less Congestion of people \\
\hline Safe & Safe & Classy and beauty \\
\hline New traffic system & New traffic system & Safe \\
\hline Cleanliness & Properly structured & Attractive \\
\hline $\begin{array}{l}\text { Can walk freely without worrying } \\
\text { about accidents }\end{array}$ & Very good environment & New traffic signals \\
\hline Enough pavements & Like to walk & Cleanliness \\
\hline $\begin{array}{l}\text { Troubling when need to get the } \\
\text { bus }\end{array}$ & Ease to walk & Inviting to walk more \\
\hline Feel more to visit and walk & Feel more to visit and walk & The area is eye-catching \\
\hline Never solve the traffic jam & Good for walkers not for vehicles & Safe pedestrian crossing \\
\hline $\begin{array}{l}\text { Feel proud to walk with these } \\
\text { newest changes }\end{array}$ & $\begin{array}{l}\text { Need some seats to sit where } \\
\text { pavements are more wide }\end{array}$ & Feel more to visit and walk \\
\hline Healthy environment & Too large pavement & Less accidents \\
\hline $\begin{array}{l}\text { Impressed color codes of } \\
\text { pavements }\end{array}$ & $\begin{array}{l}\text { Need to spend more money, time and } \\
\text { effort for short distances by vehicle }\end{array}$ & $\begin{array}{l}\text { Increase liking walking and visiting } \\
\text { to the same place }\end{array}$ \\
\hline Increased traffic on road & $\begin{array}{l}\text { Need the help of traffic policeman } \\
\text { further }\end{array}$ & $\begin{array}{l}\text { People neglect the established } \\
\text { traffic rules }\end{array}$ \\
\hline Comparably good & People break the traffic rules & Safe and ease crossing system \\
\hline Need benches & & $\begin{array}{l}\text { Earlier, Congested and hot at noon } \\
\text { times }\end{array}$ \\
\hline \multirow[t]{7}{*}{ Traffic problem has not solved yet } & & So feel cared on street \\
\hline & & No risk of vehicle accidents \\
\hline & & Shady \\
\hline & & No congestion \\
\hline & & Eye catching material colors \\
\hline & & Traffic is increasing \\
\hline & & $\begin{array}{l}\text { Need some seats to sit where } \\
\text { pavements are more wider }\end{array}$ \\
\hline
\end{tabular}

Table 4 : User views about the present environment Compiled by Author 


\section{Prior to the redevelopment}

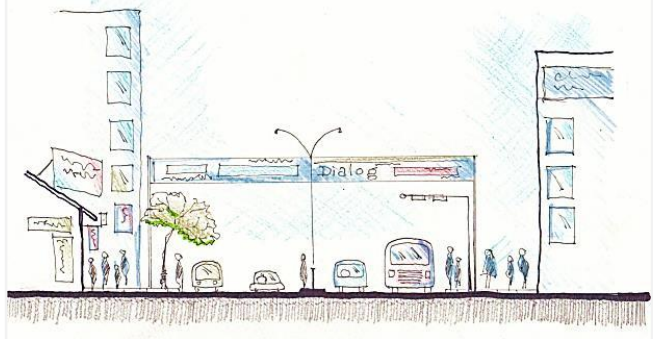

After the redevelopment

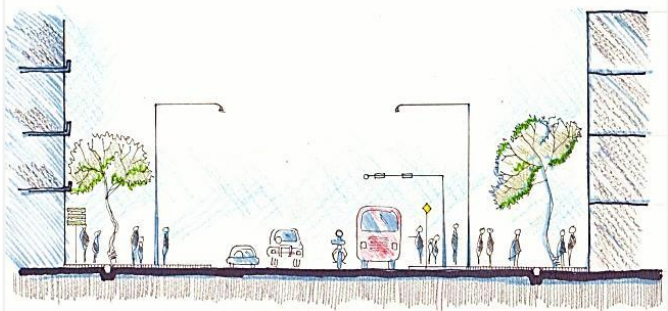

Figure 08: Cross section of the Galle road at Bambalapitiya junction and the vicinity (BJV) Compiled by Author

The present changes of the environment reflect through comfort, clean, shady and impressed environment as user's expected, but vehicular traffic, losses of street vending places as an experience which are unexpected at BJV(see table: 04). Also, user expectation on the others' behavior is supportive for the new environment. The users' experiences prior to the changes of the BJV describe, as congested and high vehicular traffic at peak hours, the colors of landscapes, the arrangement of the two-way traffic system, and the structure of the middle island of the road with street light post alike are the experience which remembered. (See figure: 08)

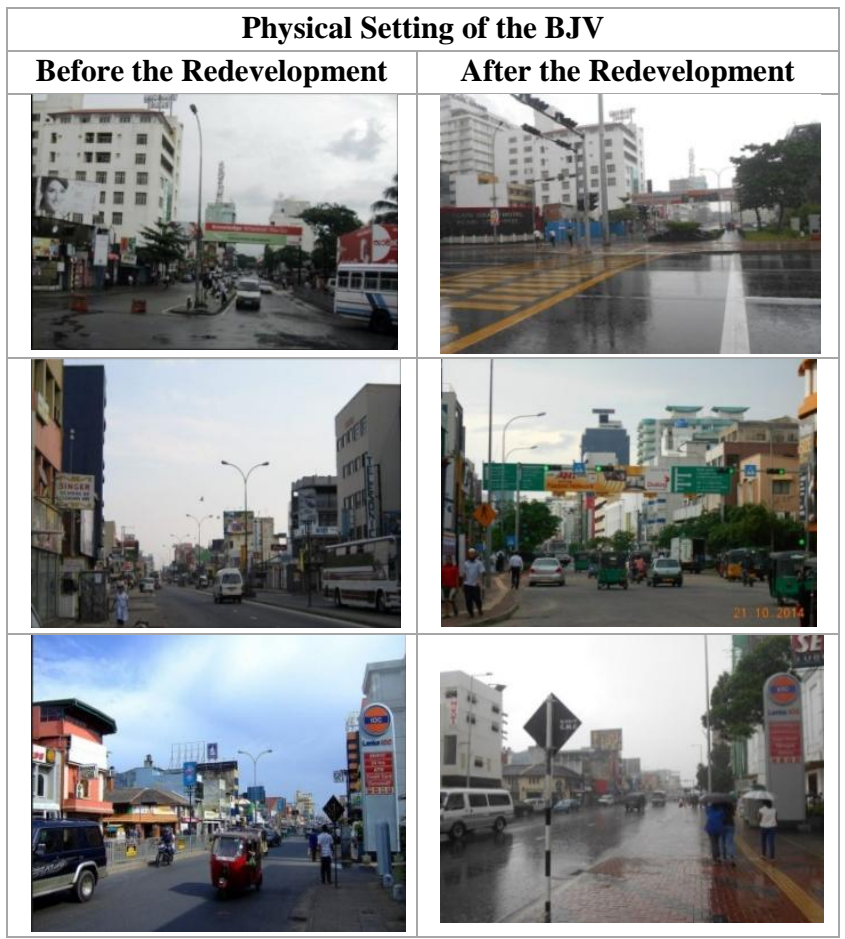

Figure 09: Views of BJV before and after the redevelopment

Prior to the redevelopment

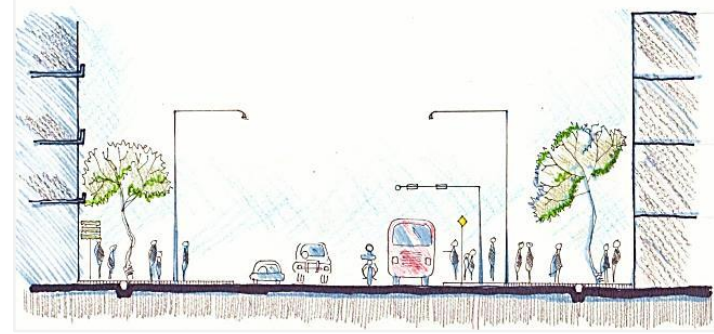

After the redevelopment

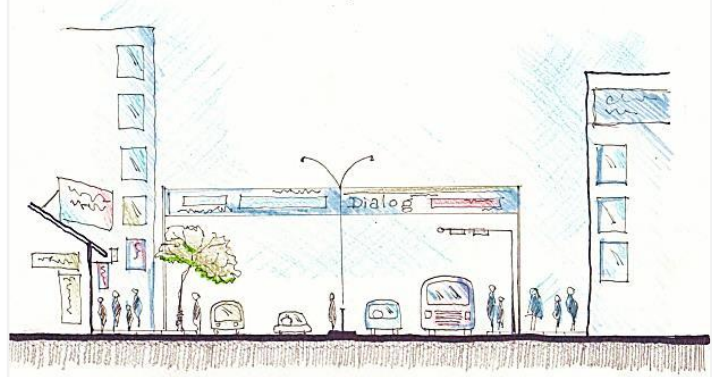

Figure 10: Cross section of the Galle road at Wellawatta junction and the vicinity (WJV) 
The users' experiences which had prior to the changes of the WJV describe as Crowded, noisy and congested with high vehicular traffic at peak hours, and also kovils were the memorable landmarks remembered in the past situation. The major changes reflect as, removing of middle street light post beside to the road, adding street tree lines beside the road, wider pavements, and new street elements such traffic signals, advertising boards have been introduced. (See Figure: 10)

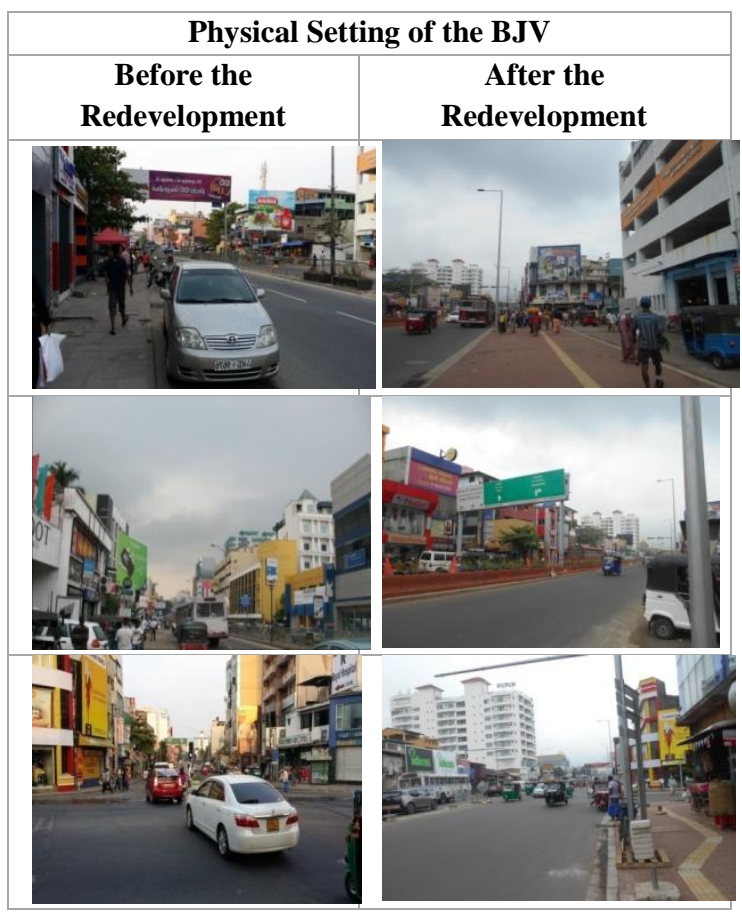

Figure 11: Views of the WJV before and after the redevelopment

\section{The User Behavior in the Changing Environment}

Interactions between the evolving environment and changing the perceived place character can be identified based on the user's experience in three distinct locations. As demonstrated the use of the environment and the user are highly diverse. As well, the user, the activity and their distribution, intensity create the rhythm across the time. All those who interact with the place in any way are, live in it, work in it, pass through it, repair it, control it, profit from it, suffer with it, and even dream about it. User's responds to this new environment reflect what things are being changed as per the actions upon the environment.
The passive and active observation supported to identify the phenomenon of the user's response upon the place as a transactional process by Wapner illustrated.

The interviewees' responses reflect the preconceived idea of the user in the same place as their cognition internally to them and externally to the previously experienced in the same place. It is direct to interact with the new environment, providing the selected three locations; it can be identified as a respectable example to SIRN theory. In 2009, two-way traffic system got changed at KJV, BJV as offering a new experience for the user. Many respondents describe this phenomenon as a new experience; based on that, the road crossing activity got changed with newly developed traffic signal system, daily routing patterns of movement got changed, also increasing traffic on the road at peak time are the identified phenomenon in the KJV, BJV and WJV. Essentially, this phenomenon reflects changes of physical attributes influence to change the place character by user's experiences. (See table: 05)

\section{Interactions between the Evolving Environment and Changing the Perceived Place Character}

The KJV, BJV and WJV consisted with commercial, administrative, residential as well religious land uses. Those had faced several influences in time to time and still stands and fulfill multiple functions as connector among few roads, as a junction where people gather.

Upon the created changes by the external interventions, the user's interaction can be interpreted as per the SIRN model. Accordingly the model's, the internal inputs are the user's memory, knowledge, and experience themselves in regards to the particular place had. Such as the situation of converting a two-way traffic system into a one-way traffic system, memory regarding elements there and their experience which had day to day behavior supporting it. 

the place: an SIRN Approach

\begin{tabular}{|c|c|c|}
\hline \multicolumn{3}{|c|}{ Past experiences of the Users } \\
\hline KOLLUPTIYA & BAMBALAPITIYA & WELLAWATTA \\
\hline $\begin{array}{l}\text { Kollupitiya junction with } \\
\text { common market building }\end{array}$ & $\begin{array}{l}\text { Congestion of people, sound of } \\
\text { vehicle horns and fast running } \\
\text { vehicles }\end{array}$ & $\begin{array}{l}\text { Congested with people and } \\
\text { vehicles } \\
\text { Kovil }\end{array}$ \\
\hline $\begin{array}{l}\text { Kollupitiya junction with } \\
\text { roundabout and movements of } \\
\text { the busy people's }\end{array}$ & $\begin{array}{l}\text { Majestic City building and two- } \\
\text { way traffic on the road }\end{array}$ & Kovil and front of flower selling \\
\hline $\begin{array}{l}\text { Methodist school and 'carnival' } \\
\text { ice cream shop }\end{array}$ & $\begin{array}{l}\text { Two-way traffic on road and } \\
\text { railway station }\end{array}$ & $\begin{array}{l}\text { Crossing the road violently } \\
\text { when huge traffic. Congested } \\
\text { and hot in noon times }\end{array}$ \\
\hline $\begin{array}{l}\text { Methodist school and 'carnival' } \\
\text { ice cream shop } \\
\text { Middle of the fences on the } \\
\text { Galle road and hectic } \\
\text { movements of the people }\end{array}$ & $\begin{array}{l}\text { More people gathering and } \\
\text { chatting such as more congested } \\
\text { environment and maroon color } \\
\text { Majestic city building }\end{array}$ & $\begin{array}{l}\text { Old buildings and kovil, } \\
\text { vehicles and bus travelling } \\
\text { sound, vehicle horn }\end{array}$ \\
\hline $\begin{array}{l}\text { McDonalds food shop and } \\
\text { jewelry shops(Vogue, } \\
\text { Swarnamahal, etc) }\end{array}$ & $\begin{array}{l}\text { Middle of road Street lights with } \\
\text { two-way traffic }\end{array}$ & $\begin{array}{l}\text { Crowded area with the people, } \\
\text { Noisy and vehicle sounds }\end{array}$ \\
\hline $\begin{array}{l}\text { Earlier, People used the road in } \\
\text { generally }\end{array}$ & $\begin{array}{l}\text { Earlier, we (traffic policeman) } \\
\text { had to manually do the } \\
\text { commands at every time, as } \\
\text { without having traffic signals in } \\
\text { every point of crossing, etc }\end{array}$ & $\begin{array}{l}\text { Earlier, I (pedestrian) have just } \\
\text { gone on the street only }\end{array}$ \\
\hline $\begin{array}{l}\text { fed-up with dust, ugly and } \\
\text { sunny environs which had } \\
\text { earlier }\end{array}$ & $\begin{array}{l}\text { earlier, I (passenger) used to } \\
\text { travel by bus because area was } \\
\text { so congested on the } \\
\text { pavements(dust, vendors, rough, } \\
\text { etc) }\end{array}$ & $\begin{array}{l}\text { I (pedestrian) walked with rough } \\
\text { and dust surface }\end{array}$ \\
\hline $\begin{array}{l}\text { Earlier, Time saving } \\
\text { arrangement of traffic system }\end{array}$ & Earlier, which had a dull look & $\begin{array}{l}\text { I (pedestrian) used to walk more } \\
\text { now rather earlier }\end{array}$ \\
\hline \multirow[t]{2}{*}{ Business are good at earlier } & $\begin{array}{l}\text { Selling was normal than } \\
\text { previous }\end{array}$ & Earlier, Business are normal \\
\hline & Used to walk & \\
\hline
\end{tabular}

Table 05 : Past experiences of the User

Compiled by Author

And the external inputs can be identified as the attributes of the physical environment had in there. Then these two inputs interact at the one point at one time and the output may be introducing new development as a one-way traffic system have experienced today. The brains of users have got complex interaction with the past experience and the memories. Finally user's has adapted their behavior accordingly new environment. By the way that sees how the others behave correspondingly. This kind of transactional process is operating when offer the new environment to the dynamic user of it. The users have had some effort to familiarize the changes made by the planning authorities. Actions reflect the way the interaction as a transactional process between people and the environment. Thus, people do something to interact with the new environment, which reflect as their various response/activities upon the environment. The user had the experience to cross the road manually and generally prior to a change of the environment. Afterward, introducing new traffic signal system, users have to do crossing an order giving by the system. Therefore, they have to follows the orders as expectedly or an unexpectedly. 


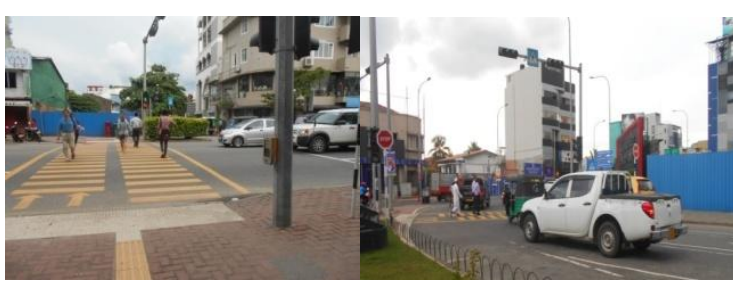

Figure 12: User Acceptance/Behave in the new environment at BJV

Contrariwise, they have done the orders concerning the majorities' behavior. As per SIRN, people follow the others' behavior to familiarize the place. It is governed by the way that sees how the others behave. Therefore, user reproduces the place by conforming to the order set by the new place and thinking of changing the place for their convenience.

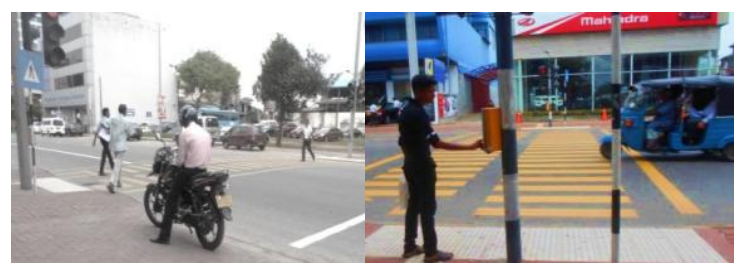

Manual and general way Acceptance /behave in of crossing BJV the new environment BJV

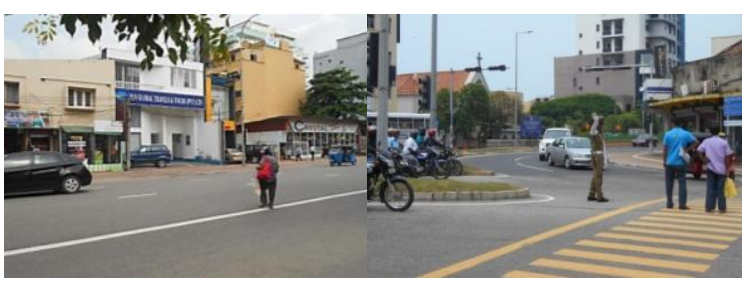

Negotiation/modification, Re-offering /Re-Acceptance

Figure 13: Road crossing at KJV as a transactional process

Occasionally, people who are not willing to accept all these changes, do the negotiations with the opposite as neglecting the rules manipulated by the government. For that, the government will have to re-offer the traffic police service may have to control the traffic system in the new environment. This may be one response which does government to solve the traffic on the road, but there may be several actions to take place such as introducing new fence beside or/and middle of the road, etc., correspondingly described by the interviewees (see table: 06).

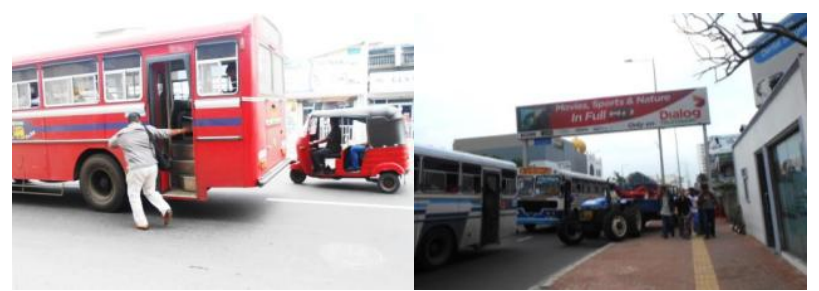

Figure 14: People Negotiation/Modification in the new environment at BJV

\begin{tabular}{|c|}
\hline $\begin{array}{l}\text { Users' aspirations of transaction between the } \\
\text { user and the environment in the future }\end{array}$ \\
\hline Need more trees for shade \\
\hline $\begin{array}{l}\text { Need some areas to sit and chat or waiting and } \\
\text { meeting }\end{array}$ \\
\hline Need keep maintenance the environment \\
\hline Need benches \\
\hline Need renovation and modification of buildings \\
\hline $\begin{array}{l}\text { Need some changes like small 3-4 seating spot } \\
\text { near to shade trees, more eating shops and small } \\
\text { café shops }\end{array}$ \\
\hline Never solve the traffic problems \\
\hline $\begin{array}{l}\text { Need modification of buildings which are } \\
\text { having odd and dull look }\end{array}$ \\
\hline $\begin{array}{l}\text { Need well maintenance to up keep the } \\
\text { environment clearly }\end{array}$ \\
\hline People will break the traffic rules \\
\hline $\begin{array}{l}\text { Need some seats to sit where pavements are } \\
\text { more wide }\end{array}$ \\
\hline $\begin{array}{l}\text { Need to spend more money, time and effort for } \\
\text { short distances by vehicle }\end{array}$ \\
\hline Need the help of traffic policeman \\
\hline People will familiarize to this new environment \\
\hline People will appreciating on these new changes \\
\hline Need space to vending \\
\hline $\begin{array}{l}\text { Need to change Building shape and its materials } \\
\text { accordingly the environment, if so place feels } \\
\text { more luxurious }\end{array}$ \\
\hline Need some dustbins \\
\hline
\end{tabular}

Table 06: Users' aspirations of the future Compiled by Author 
With the government decision of creating redevelopment of the Galle road, most of the street vendors have to formalize their vending location where formal places established. The interviews and the observation indicate, providing a formal place may not economically beneficial than the informal place on the street which everyone can see and have an easy access similarly.

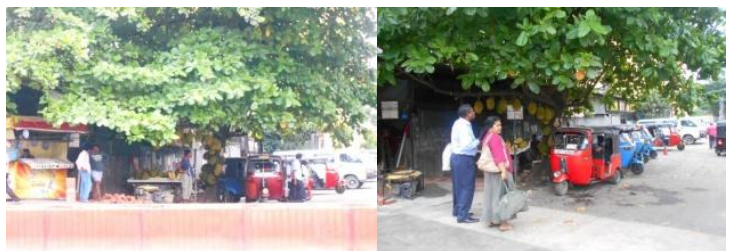

Figure 15: People Negotiation/Modification in the new environment at WJV

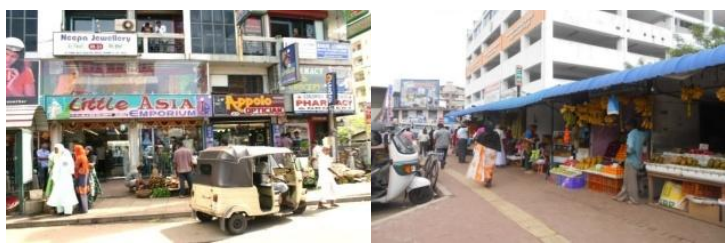

Offered environment-Pavement Vending Acceptance/Behave in the new environment

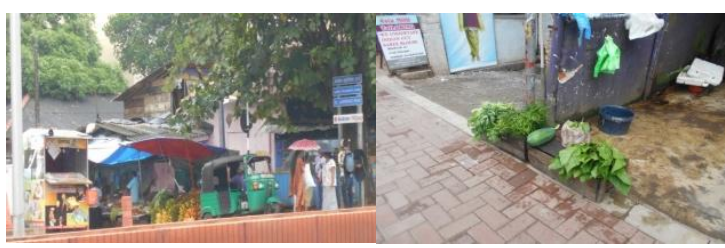

Negotiation/Modification in the new Environment

Figure16: User's behavior in the new environment at WJV

Soon after redeveloped the environment, the street vending is hesitated by the new appearances of a formalized place, but as an everyday actions of the user's, they invite to vendors on the street at same place creating the same place character. This can be mainly identified in WJV noticeably. Some residual spaces, edges such as the space under the trees used to carry on their daily business activities as a usual.

The situation is different for the lottery sellers and the pavement vendors in KJV and BJV. Pavement Venders have to give up the place with the government intervention of evicting the vendors on the pavement to create the comfort place for pedestrian and the city beautification. However, as a transactional perspective, again vendors do the vending by walking with hanging the things to sell. User's also following the vendors at noon time predominately.
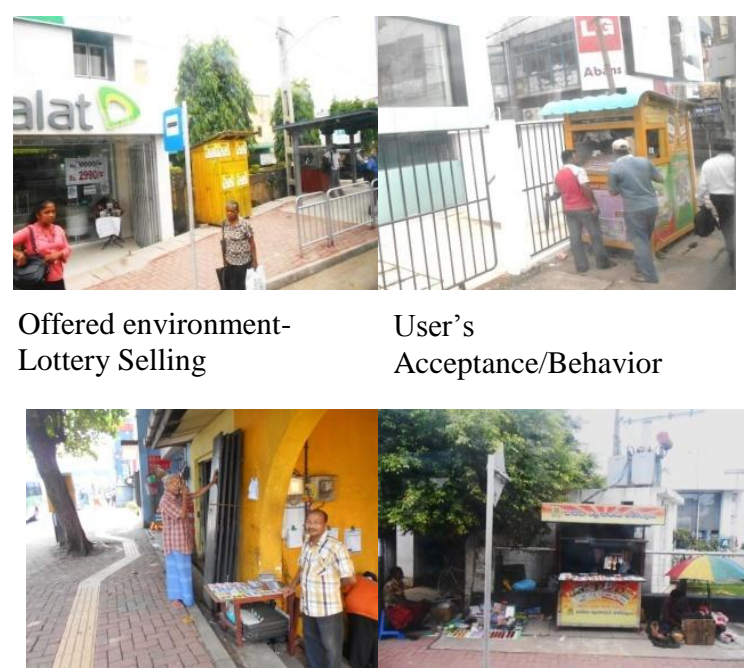

Negotiation/Modification Re-Offered environment in the new Environment

Figure17: Lottery Selling at KJV as a transactional process

In summation, passive observation at the each junctions describes that most of the users cross the road without concerning traffic signal lights at various points on the Galle road, some street hawkers such as lottery sellers, fruit sellers, home ornament sellers, etc., Have moved again on to the street edges, front of shops or empty spaces on the pavement to keep on their selling continuously.

KJV and BJV most of the lottery sellers had to selling by walking because their lottery boxes were removed. Since, people who wish to buy have to wait or follow the sellers Also, now most of the small retail shops owners are complaining that they are having less business activities due to the changes in the bus stops. Small scale businesses such as retails, food café, tea shops, even shopping show rooms are now converting their businesses to alternatives for comply with the current demands while some have already relocated their businesses to another locations as such they moved to side of the people gathering, moving and getting for public transport services of the side of bus stops located in Galle road, KJV. Most 
of the daily walkers passing KJV, BJV junction had change their routing pattern to find the bus transportation due to the changes in the traffic system (See table:05). Meanwhile most of them are glad to walk on the pavements due to the newly built pedestrian friendly pavement design.

The first level of common attributes in three locations are figured out (See table:04) which describes the changes in specific attributes of the environment directly influence to the user's experiences, on the other hand, the transactions between the environment and the user are exposed. The changes of the attributes directly influencing to the users' experiences are related to,

1. Visual aspect of Pedestrian pavements: Width, materials (rough/soft), Color

2. Elements of the street: tree lines, sign boards, traffic signals, crossing points, bus stops, parking bays

3. Sentimental aspect of the environment which reflects through physical setting such as Shady, Cleanliness, Safe, Comfort, Quiet, etc.

First level attributes explain, the basic requirement of place perspective from the user's user experience as Comfort, Cleanliness, Safe, Seating, Relax, Pleasant, Healthy and Shady has to accomplish as the basic requirement to make a habitable place first and fore mostly. Therefore, any of those are undeniably basic attributes for any effort of place making in the contemporary context of urban planning.

As table 5 describes, the attributes that are explicating the how the user experiences form changes in attributes of the environment; On the other hand, which reflects what way those transactions are happing. Essentially findings indicates, like to walk often, free and easy access, no congestion, safe on street, changes of daily movement pattern, violating traffic rules, user have to more effort for finding public transportation, increase the road vehicular traffic, etc., which are the second level of attributes according to ranking. It is much clearer that each and every attribute of physical environment is related to the users' experience, and then influence to form the place character based on the user behavior on the environment.

\section{Future Aspiration of the Users}

1. Users expect to interact with the new environment further fulfilling above requirements trees for shady further

2. Seating Arrangement

3. Traffic Problem

4. Renovation and modification of the buildings

Above each of the respondents describes their aspiration of the future considering new necessities are implies person's desires are continuous as their behavior. Hence Wapner has revealed, any environment is an ever evolving therefore, its user cannot stay as a static; they also have to interact with the process of evolving. This is what describes places and its character is on evolution as revealed by the findings lastly.

The streets have their own characteristics which are appearing through various situations. It can be identified as contested and negotiated spaces (Yeog, B., 2003). The street links places as well it is a place itself, which delivered its space an opportunity to do several kinds of activities. Hence, it is a space which is to come to give meaning by its users.

The government conventional aspiration on clean and well organized and pedestrian friendly road with beautification led the road in the transaction between the users of it. Because, User is the dynamic person closely interacts with the place. So they are the major driving force to build to modify, to remove or even vanish the place character. The user's experience and the memory are guided to behave, to accept, to negotiate the new place with the preconceived idea of the location had. It is come out of their experience of the place at previous occasions. The behavior is governed by the way that user's sees how the others behave.

Therefore, they reproduce the space by conforming to the order set by the new place and thinking of changing the place for convenience at instances. Hence, the character of the place is largely shaped by the user's 
view, experiences of the place of its past and the future as described by the finding of interpretation in the transactional process.

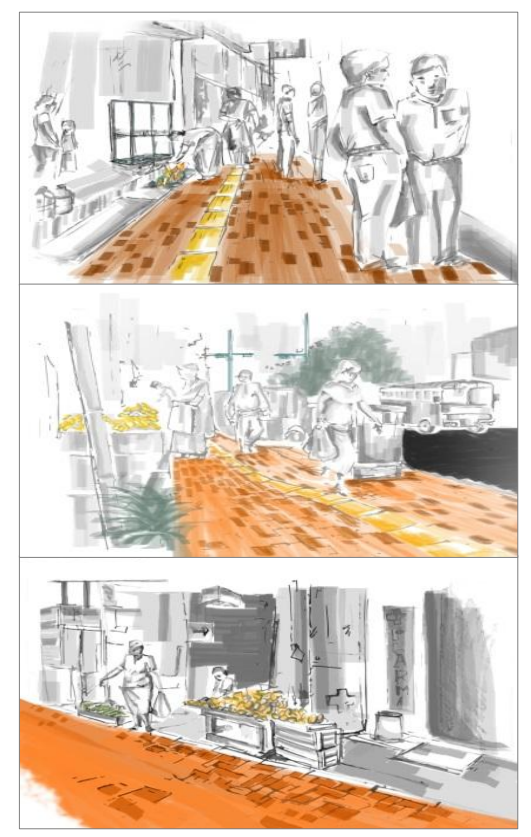

Figure 18 : User's interactions in the evolving environment

The user's experience and the memory are guided to behave, to accept as well as to negotiate the new place with the preconceived idea of the location had (see figure:18) This has come out of their experience of the place at previous occasions. The behavior is governed by the way that user's sees how the others behave. Therefore, they reproduce the space by conforming to the order set by the new place and thinking of changing the place for convenience at instances. Hence, the character of the place is largely shaped by the user's perception, experiences of the place of its past and the future as described by the finding of interpretation in the transactional process.

\section{Conclusions}

Urban dynamics are general. Nonetheless, city developers should be aware of the fact that the experience of the user gets from the environment is an offer from the responses of the users, but not the exact offerings by the planning authorities. The relationship between the user and the environment is on a 'Transactional process' which produce the places which we live in, on the other hand the 'character' which we cognizant.
As per the Transactional phenomenon, the selected nodes have their own characteristics which are emerging through several interventions on the several contexts over the years. The users of the place are the dynamic agents which subjects to originate its unique character fairly considering the others' behavior. Place character enriches significantly when the user interaction with the environment such as users acceptances, behavior, negotiation or modification and reoffering. It is a continuous process which significantly shapes the place and its character over the several interventions as discussed under the selected nodes in the analysis based on this 'Transactional process'.

Basically, as model explains, the decision making process of user's is an internal and an external transactional process between user's cognition and the environment. The memory of the place and its ongoing processes are internalized to reconstruct the place in the user's memory and to deliver the behavior in places.

A memory, cognition of the Place is an internally representing previous experience and knowledge about the place in general. The middle of the agent who/whom going to plan the city or a place is needed to aware carefully of the on-going interaction between internal and external sequential process of the users. The issue of the contemporary planning is that, they only limited to the external representation into limited physical attributes or the most essential needs of people as much instantly.

In a planning standpoint, planners and urban designers generally conceptualize a 'Place' and the character of it as a static state and do the plan and design for that. But, the urban Street is a place, where every movement is going through, Where people gather, where the conventional planning practices ensure the city developers' aspiration as well as where the familiarity challenge by external intervention. Thus undeniably streets behave entirely a different manner regardless of city developers' aspiration in this public as well political arena. 


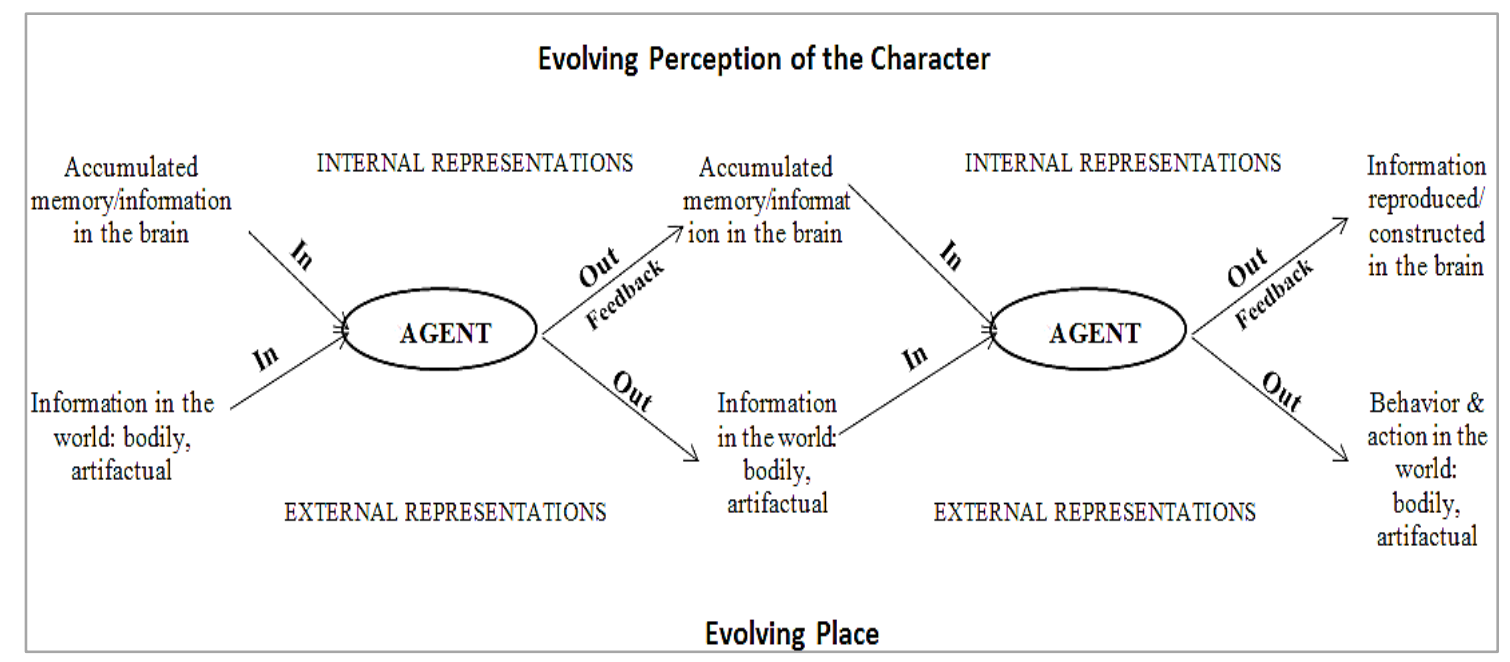

Figure19: Developed model applying the SIRN Model Complied by Author

"Everywhere there are situations, territories, rules and regulations, and everywhere there are transgressed" (Dovey, 2013.) Hence, the policy makers' or city developer's attempts are wasting without understanding the user's behavior of the place and its character. Because, when their expected end state/aspiration is achieved, they believe the state has to be maintained; or if the expectations could not be achieved then there is a frustration and additional efforts to 'correct' the situation back to what was expected but however failed to achieve.

Similarly, the usual gap in contemporary planning practices is non-conscious of the internal representation of the user memory, the experience of the place. Most often only focus on the external representation such physical attributes of the place while planning. This is the reason for users' modification/negotiation over the acceptations. The most prevailing challenge to the profession of urban planning at the contemporary is how to formalize the place or the city answering to this everevolving phenomenon of our environment.

Policy Makers, Planners and designers are essential to understand the 'Place' as an 'evolving phenomenon' hence its character also has to evolving. Thus, it is getting offered, accepted / behaved, negotiated / modified and re-offered from time to time which is central to plan or design the physical environment to facilitate this transactional process and not the end product. Because, place making is a vague and complex scenario, which should need to consider both individual and collective levels and the experience of the inhabitant to create the city or a place as a common reservoir or a collective memory not only on the physical environment as mostly concern today. 


\section{REFERENCES}

Anderson, A. (1978) On Street. Cambridge: The MIT Press.

Clare, L., Twigger, R., David, L. \& Uzzell (1996). Journal of Environmental Psychology, 16(2), 205-220.

Couch, C., and Dennemann, A. (2002). Urban regeneration and sustainable development in Britain: The example of the Liverpool Ropewalks Partnership. Cities, (17)2,137-147.

Dayaratne, R.(2000). An examination of the Asian and Sri Lankan Urban Space. Built-Environment - Sri Lanka, (1) 2.

Dayaratne, R., and Rajapakse, A. (1998). Towards Place-Sensitive Urban Interventions: An Examination of the Significant Characteristics of Place in Selected Urban Nodes in Colombo. Built-EnvironmentSri Lanka, (1)1.

Dovey, K. (2008). Mediating Power in Built Form. Framing Place, Oxon: Routledge.

Dovey, K. (2011). Informal Urbanism and Complex Adaptive Assemblage. International Development Planning Review, P. 349-367.

Fernando, N. (2000). An Analysis of the Changing Character of an Urban Street: A Case Study of the Galle Road, Colombo. Built- Environment-Sri Lanka, (1)2.

Forsyth, A., and Southworth, M. (2008). Cities A foot-Pedestrians, Walkability and Urban Design. Journal of Urban Design, (13)1, 1-3.

Moore, G.T. (2006). Environment, Behavior and Society: A Brief Look at the Field and Some Current EBS Research. University of Sydney, Australia.

Jacobs, A. (1993) Great Streets. Cambridge: The MIT Press.

Jacobs, J. (1961). The Death and Life of Great American Cities. New York: Vintage Books.

Jivén, Gunila, Larkham, and Peter, J. (2003). 'Sense of Place, Authenticity and Character: A Commentary'. Journal of Urban Design, (8)1, 67-81.

Lynch, K. (1960). Image of the city. New York: MIT Press.

Lefebvre, H. (1991).The Production of Space. Oxford: Blackwell.

Mehta, V. (2009). Look Closely and You Will See, Listen Carefully and You Will Hear: Urban Design and Social Interaction on Streets. Journal of Urban Design, (14)1, 29-64.

Mehta, V. (2013).The Street: A Quintessential Social Public Space. New York: Routledge.

Munasinghe, J. N., (2004). An Approach to Conceptualize the Environmental Image for Planning. An Unpublished PhD Thesis, National University of Singapore.

Nasar, J.L. (1997). The evaluative image of the city. New York: Sage publication.

Oktay, D. (2002).The quest for urban identity in the Changing context of the city - Northern Cyprus. Cities, (19)4, 261-271.

Portugali, J. (2002). The Seven Basic Propositions of SIRN (Synergetic Inter- Representation, Nonlinear Phenomena in Complex Systems. Journal of Environmental Psychology,(5)4.

Portugali, J. (1996). Inter-representation networks and cognitive maps: The construction of cognitive maps. Environmental Psychology, 11-43. 
Portugali, J. (1999). Synergetic Cities II: Pattern Recognition, Cognitive Mapping and Decision-Making. Self-Organization and the City, Berlin: Springer.

Relph, E. (1976). Place and Placelessness. London: Pion.

Rapoport, A. (1977). Human Aspects of Urban Form. New York: Pergamon.

Sjalaladdini, S, and Oktay, D. (2012). Urban Public Spaces and Vitality: A Socio-Spatial Analysis in the Streets of Cypriot Towns. Behavioral Sciences, (l)35,664-674.

Schulz, C.N. (1976). The Phenomenon of Place. Cambridge: MIT Press.

Schulz, C.N. (1980). Genius Loci towards Phenomenology of Architecture. New York: Rizzoli International Publications.

Wunderlich, F. M. (2008). Walking and Rhythmicity: Sensing Urban Space. Journal of Urban Design, (13)1,125-139. 